\title{
Carbon dioxide as a carbon source in organic transformation: carbon- carbon bond forming reactions by transition-metal catalysts.
}

\author{
$\operatorname{AUTHOR}(\mathrm{S}):$ \\ Tsuji, Yasushi; Fujihara, Tetsuaki
}

\section{CITATION:}

Tsuji, Yasushi ... [et al]. Carbon dioxide as a carbon source in organic transformation: carbon-carbon bond forming reactions by transition-metal catalysts.. Chemical communications 2012, 48(80): 9956-9964

ISSUE DATE:

2012-08-02

URL:

http://hdl.handle.net/2433/180280

\section{RIGHT:}

(C) The Royal Society of Chemistry 2012.; This is not the published version. Please cite only the published version.; この論文は出版社版で ありません。引用の際には出版社版をご確認ご利用ください。 


\title{
Carbon Dioxide as a Carbon Source in Organic Transformation: Carbon-Carbon Bond Forming Reactions by Transition-Metal Catalysts
}

\author{
Yasushi Tsuji* and Tetsuaki Fujihara \\ Recent carbon-carbon bond forming reactions of carbon dioxide with alkenes, alkynes, dienes, aryl zinc compounds, aryl boronic esters, \\ aryl halides, arenes having acidic $\mathrm{C}-\mathrm{H}$ bonds are reviewed in which transition-metal catalysts play an important role.
}

\section{${ }_{10}$ 1. Introduction}

Carbon dioxide $\left(\mathrm{CO}_{2}\right)$ is an ideal carbon source owing to its abundance, low cost, nontoxicity, and good potential as a renewable source. ${ }^{1}$ However, it is not easy to activate such a thermodynamically and kinetically stable material. Therefore, 15 catalysts must play an important role to develop useful transformations utilizing this attractive and environmentally friendly raw material. In this review article, recent progress on utilization of $\mathrm{CO}_{2}$ in carbon-carbon bond forming reactions is surveyed. Such survey will offer basic idea to employ $\mathrm{CO}_{2}$ as an 20 attractive carbon source in organic transformations. There have been several excellent reviews on a similar subject. ${ }^{2}$ On the other hand, carbon-oxygen bond and carbon-hydrogen bond forming reactions of $\mathrm{CO}_{2}$ are also important for syntheses of organic carbonates (including $\mathrm{CO}_{2}$ /epoxide copolymerization), formic 25 acid derivatives, and methanol. However, these reactions are not covered in the present article, since several useful reviews are available. $^{3 \mathrm{~d}-\mathrm{g}, 4 \mathrm{e}-\mathrm{h}}$

\section{Stoichiometric reaction relevant to catalysis with $\mathrm{CO}_{2}$}

\section{${ }_{30} \mathbf{2 . 1}$ Transition metal complexes bearing $\mathrm{CO}_{2}$}

In order to develop efficient catalytic reactions, fundamental behaviours of $\mathrm{CO}_{2}$ in the presence of a transition metal complex must be understood. As the first isolated and characterized metal $\mathrm{CO}_{2}$ complex, Aresta et al. prepared $\left[\mathrm{Ni}\left(\mathrm{CO}_{2}\right)\left(\mathrm{PCy}_{3}\right)_{2}\right](\mathrm{Cy}=$ 35 cyclohexyl) complex in 1975 by treating $\left[\mathrm{Ni}\left(\mathrm{PCy}_{3}\right)_{3}\right]$ or $\left[\left\{\mathrm{Ni}\left(\mathrm{PCy}_{3}\right)_{2}\right\}_{2} \mathrm{~N}_{2}\right]$ with $\mathrm{CO}_{2}$ in toluene. (Scheme 1). ${ }^{5}$ The $\mathrm{CO}_{2}$ coordinates to the electron rich $\mathrm{Ni}(0)$ centre as $\eta^{2}$ form. This finding suggested that $\mathrm{CO}_{2}$ could be activated on a metal centre. More relevant to catalytic reactions of $\mathrm{CO}_{2}$, Hoberg et al. found

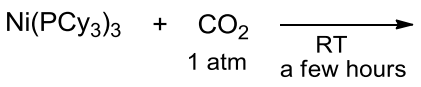

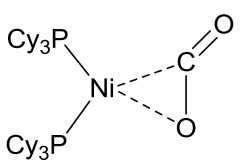

air stable red-orange crystals
Scheme 1 Synthesis of $\mathrm{Ni}(0) \eta^{2}-\mathrm{CO}_{2}$ complex.

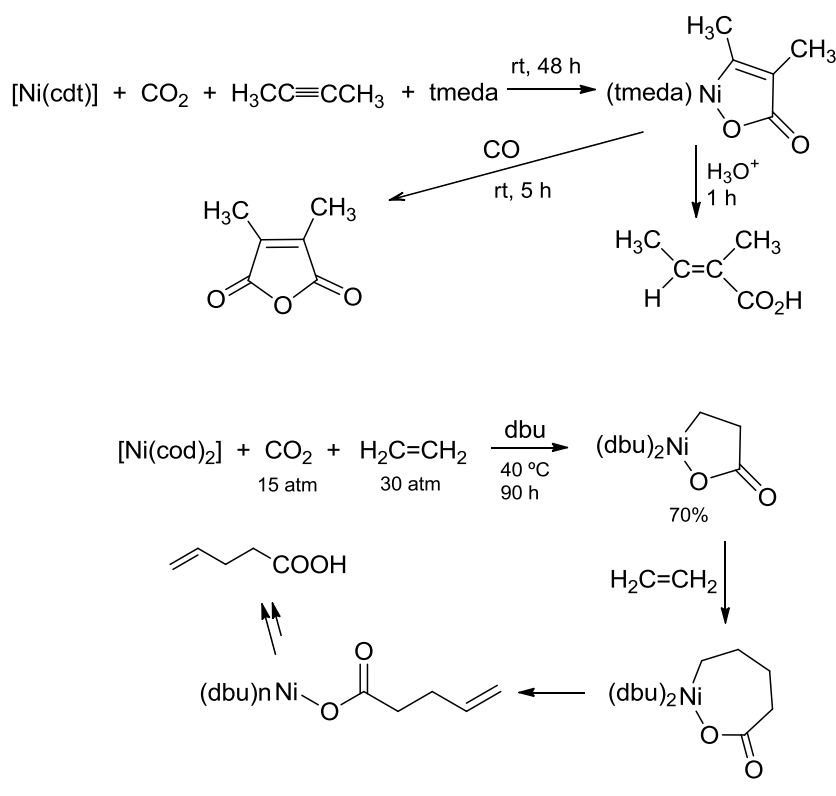

Scheme 2 Stoichiometric reaction of $\mathrm{Ni}(0)$ complex in the presence of 2-butyne and ethylene: $\mathrm{cdt}=1,5,9$-cyclododecatriene, tmeda $=N, N, N^{\prime}, N$ '-tetramethylethylenediamine, $\mathrm{dbu}=1,8$ diazabicyclo[5.4.0] undec-7-ene

40 that $\mathrm{CO}_{2}$ reacts with alkenes or alkynes in the presence of a stoichiometric amount of $\mathrm{Ni}(0)$ complexes to afford oxanickelacycles (Scheme 2). ${ }^{6}$ Even the metal complexes were used in stoichiometric amounts, useful carbonyl compounds were obtained as products. Furthermore, a wide variety of complexes ${ }_{45}$ bearing $\mathrm{CO}_{2}$ in various coordination styles $\left(\eta^{1}, \eta^{2}, \mu^{2}-\eta^{2}, \mu^{2}-\eta^{3}\right.$, etc.) have been isolated and characterized to date. ${ }^{7}$

\subsection{Seminal catalytic reactions of $\mathrm{CO}_{2}$}

A series of pioneering works for catalytic transformation of $\mathrm{CO}_{2}$ with unsaturated compounds were carried out by Inoue et al. in 50 1976-1979. ${ }^{8-\mathrm{c}}$ First, they reacted 1,3-dienes under a $\mathrm{CO}_{2}$ pressure of $50 \mathrm{~atm}$ in the presence of a catalytic amount of $\mathrm{Pd}(\mathrm{dppe})_{2}$ $\left(\right.$ dppe $\left.=\mathrm{Ph}_{2}\left(\mathrm{CH}_{2}\right)_{2} \mathrm{PPh}_{2}\right)$ at $120^{\circ} \mathrm{C}\left(\right.$ Scheme 3a) ${ }^{8 \mathrm{a}}$ They found the lactone formed from $\mathrm{CO}_{2}$ in a complex mixture of various products. In the presence of $\mathrm{Ni}(\operatorname{cod})_{2}-\mathrm{dppb}(\operatorname{cod}=1,5-$ 
(a)
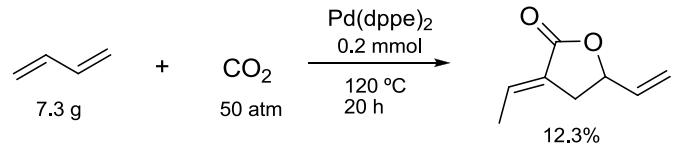

(b)

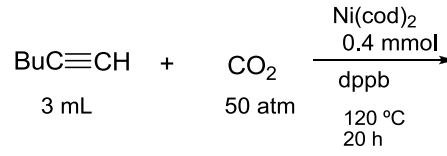<smiles>CC(C)(C)Cc1cc(C(=O)O)oc(=O)c1</smiles>

(c)

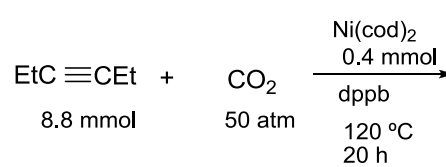<smiles>CCc1c([Sn](=O)[O-])oc(=O)c(CC)c1CC</smiles>

(d)

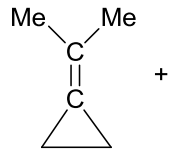

$17 \mathrm{mmol}$
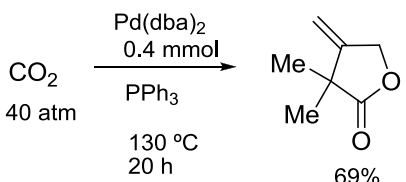

Scheme 3. Early catalytic reactions of hydrocarbon unsaturates with $\mathrm{CO}_{2}$. dppe $=\mathrm{Ph}_{2} \mathrm{P}\left(\mathrm{CH}_{2}\right)_{2} \mathrm{PPh}_{2}$, dppb $=\mathrm{Ph}_{2} \mathrm{P}\left(\mathrm{CH}_{2}\right)_{4} \mathrm{PPh}_{2}$, cod $=1,5$-cyclooctadiene, $\mathrm{dba}=$ dibenzylideneacetone

cyclooctadiene, dppb $\left.=\mathrm{Ph}_{2} \mathrm{P}\left(\mathrm{CH}_{2}\right)_{4} \mathrm{PPh}_{2}\right)$ as a catalyst at $120{ }^{\circ} \mathrm{C}$, two terminal alkynes reacted with $\mathrm{CO}_{2}(50 \mathrm{~atm})$ to afford lactones in only low yields (Scheme $3 \mathrm{~b}$ ). ${ }^{8 \mathrm{~b}}$ On the other hands, with the same catalyst system, internal alkynes provided the 5 corresponding products in much higher yields (Scheme 3c). ${ }^{8 \mathrm{c}}$ As for alkenes, $\operatorname{Pd}(0)$ catalyzed reaction of methylenecyclopropanes with $\mathrm{CO}_{2}$ (40 atm) provided lactones successfully in good yields (Scheme 3c). ${ }^{8 \mathrm{~d}}$ In these reactions, yields of the products from $\mathrm{CO}_{2}$ were not so satisfactory. However, these results clearly 10 indicated that such catalytic reactions are very useful and promising.

\section{Carbon-carbon bond forming reaction with $\mathrm{CO}_{2}$}

Carbon-carbon bond forming reactions are quite important to 15 develop a wide variety of organic transformations employing $\mathrm{CO}_{2}$. The most classical methods to realize the $\mathrm{C}-\mathrm{C}$ bond forming reaction with $\mathrm{CO}_{2}$ are the reaction with Grignard and organolithium reagents. Highly nucleophilic these reagents react with $\mathrm{CO}_{2}$ without a catalyst. However, in these reactions, many 20 useful functionalities such as ketones, esters, and nitriles are not tolerant. Thus, in order to develop transformations compatible with various functionalities, much less nucleophilic substrates must be employed. In such cases, catalysts are important and indispensable for successful $\mathrm{C}-\mathrm{C}$ bond formation reactions with ${ }_{25} \mathrm{CO}_{2}$.

\subsection{Reactions of Zinc compounds with $\mathrm{CO}_{2}$}

In place of Grignard and lithium reagents, less nucleophilic (a)

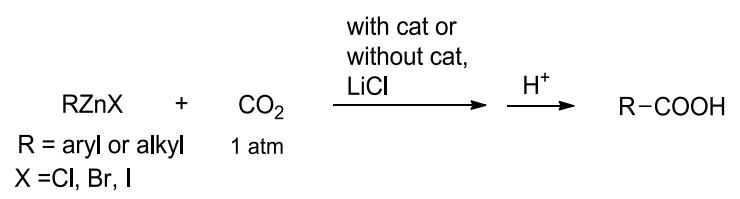

(b)

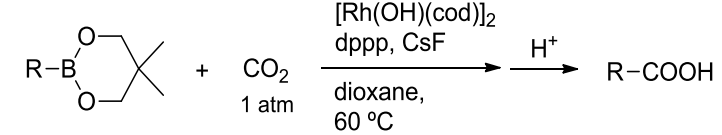

$\mathrm{R}=$ aryl or alkenyl

$\mathrm{R}=$

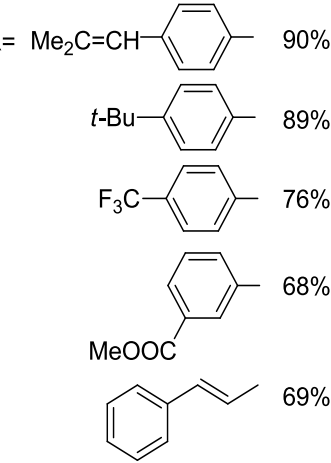

(c)

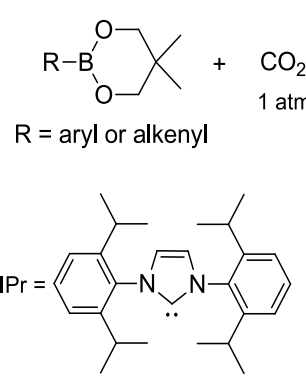<smiles>[R]OCC#Cc1ccc(C(=O)OCc2ccc([Se])cc2)cc1</smiles>

Scheme 4 Carboxylation reactions of organozinc and -borane compounds using $\mathrm{CO}_{2}$

organozinc were utilized with $\mathrm{CO}_{2}$ (Scheme 4a), since a wide variety of functionalities are compatible with organozinc 30 compounds. Yorimitsu and Oshima reported that alkylzinc iodide- $\mathrm{LiCl}$ readily react with $\mathrm{CO}_{2}$ in THF in the presence of $\mathrm{Ni}$ (acac) $)_{2}-\mathrm{PCy}_{3}$ as a catalyst to afford the corresponding carboxylic acids. ${ }^{9 \mathrm{a}}$ They found that the addition of $\mathrm{LiCl}$ was essential for the carboxylation. They claimed that the Ni catalyst 35 is indispensable for alkylzinc compounds, while $\mathrm{PhZnI}-\mathrm{LiCl}$ reacted with $\mathrm{CO}_{2}$ in THF without the $\mathrm{Ni}$ catalyst to afford benzoic acid in $36 \%$ yield. Independently, Dong et al reported that carboxylation of arylzinc bromides with $\mathrm{CO}_{2}$ proceeded in the presence of a similar $\mathrm{Ni}$ and $\mathrm{Pd}$ catalysts bearing $\mathrm{PCy}_{3}$ as a 40 ligand. $^{9 \mathrm{~b}}$ They reported that no carboxylation occurred without the transition metal catalyst. On the other hand, Kondo et al found that transition metal catalysts are not necessary for these 
reactions, but only 2.8 equiv of $\mathrm{LiCl}$ in $\mathrm{DMF}$ is sufficient for the reaction. ${ }^{9 \mathrm{c}}$ Activities of organozinc compounds seem to be varied considerably depending on reaction conditions, and some reactions really proceed without a transition metal catalyst.

\section{3.2 Reactions of organoboronic esters with $\mathrm{CO}_{2}$}

Organoboron compounds are easily prepared by various methods and are highly useful substrates in a variety of organic synthesis. Iwasawa et al. reported that aryl- and alkenylboronic esters react with $\mathrm{CO}_{2}$ in the presence of $[\mathrm{Rh}(\mathrm{OH})(\mathrm{cod})]_{2}(3$

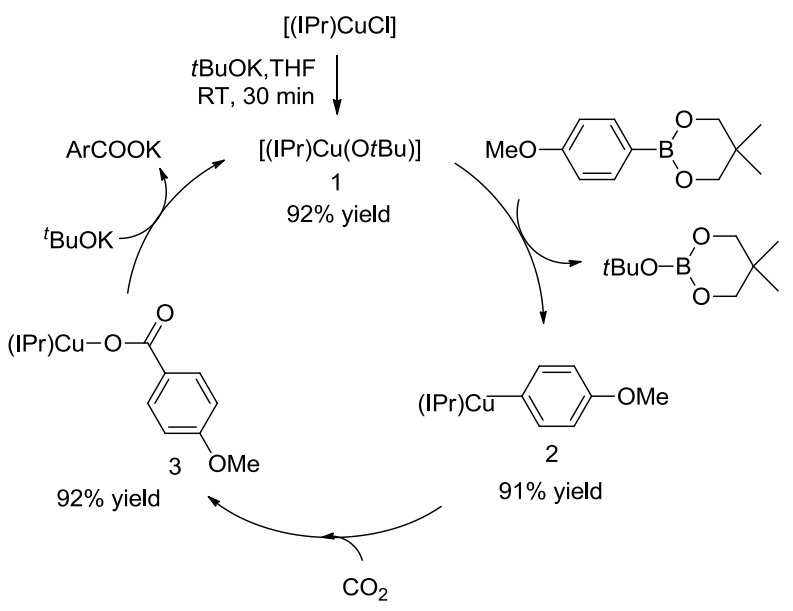

Scheme 5 Possible catalytic cycles and isolation of catalytic species in Scheme 4c

(a)
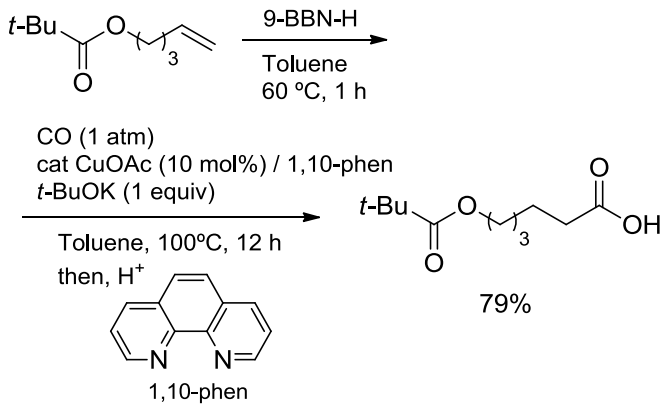

$79 \%$

(b)

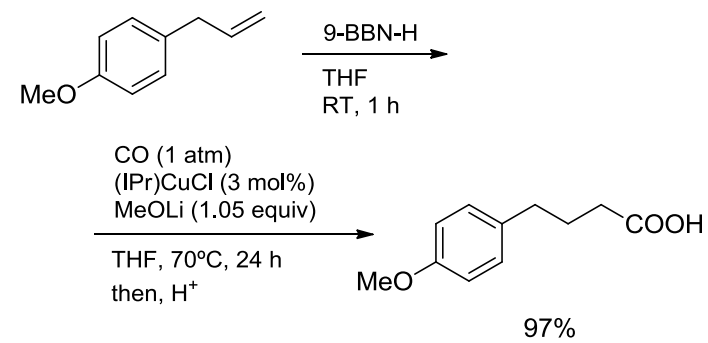

Scheme 6 Formal reductive carboxylation of terminal alkenes via hydroboration
Table 1 Nickel-mediated 1,4-double-carboxylation of 1,3-diene

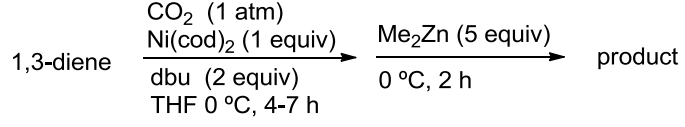

1,3-diene product

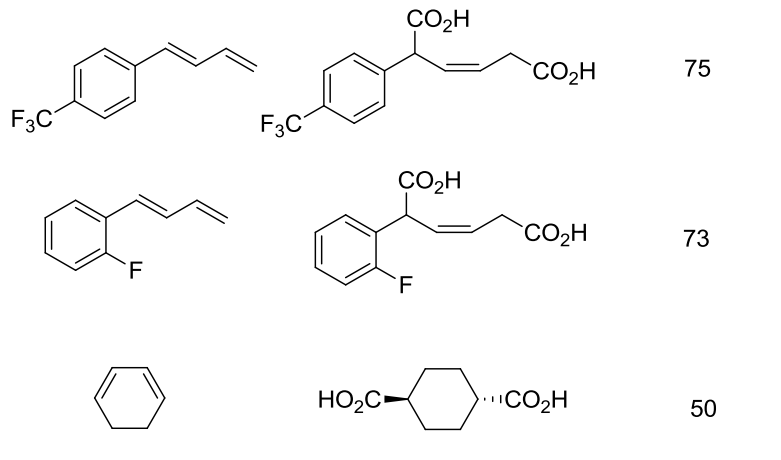

$10 \mathrm{~mol} \%)$, dppp $\left(\mathrm{Ph}_{2} \mathrm{P}\left(\mathrm{CH}_{2}\right)_{4} \mathrm{PPh}_{2}, 7 \mathrm{~mol} \%\right)$, and $\mathrm{CsF}$ (3 equiv) to provide the corresponding carboxylic acids in high yields (Scheme $4 \mathrm{~b}) .{ }^{10 \mathrm{a}}$ In the reaction, ester part of the boronic esters affected the carboxylation considerably. Actually, only 2,2dimethyl-1,3-propanediolate ester (Scheme 4b) afforded the

15 carboxylation products in high yields, while other propan1,3diolate, ethylene glycolate, pinacolate, and catecholate gave almost no products. On the other hand, insertion of $\mathrm{CO}_{2}$ into carbon- $\mathrm{Cu}$ bonds has been known. ${ }^{11}$ Hou et al. reported that the same carboxylation of organoboronic esters are possible with $\mathrm{N}$ 20 heterocyclic carbene copper catalysts, in which the same effect of the ester moiety was observed (Scheme 4c). ${ }^{10 \mathrm{~b}}$ Importantly, most copper catalytic species (2 and $\mathbf{3}$ in Scheme 5) were isolated in high yields (91\% and $92 \%$ ) and fully characterized including Xray crystal structure analysis. The mechanism shown in Scheme 5 25 was supported by DFT calculations indicating insertion of $\mathrm{CO}_{2}$ into the $\mathrm{Cu}-\mathrm{Ar}$ bond is the rate-determining step in which nucleophilic attack of the aryl moiety on $\mathrm{CO}_{2}$ affords the new $\mathrm{C}-$ $\mathrm{C}$ bond. ${ }^{10 \mathrm{c}}$ Iwasawa et al. reported similar carboxylation by a copper catalyst. ${ }^{10 \mathrm{~d}}$

30 Sawamura et al. (Scheme 6a) ${ }^{12 a}$ and Hou et al. (Scheme $\left.6 \mathrm{~b}\right)^{12 b}$ independently found that the copper catalyzed carboxylation of alkylboranes were carried out via hydroboration of terminal alkenes with 9-borabicyclo[3.3.1]nonane (9-BBN-H). The overall process represents a useful reductive carboxylation of terminal 35 alkenes with $\mathrm{CO}_{2}$.

\subsection{Carboxylations of dienes and alkenes}

Mori et al. developed carboxylation of 1,3-dienes and allenes with $\mathrm{CO}_{2}$ via allylnickel intermediates. ${ }^{13}$ When 1,3 -dienes were reacted with 1 equiv of $\mathrm{Ni}(\operatorname{cod})_{2}$ and 2 equiv of dbu under $\mathrm{CO}_{2}$, 
Table 2 Nickel-mediated arylative mono-carboxylation of 1,3-diene

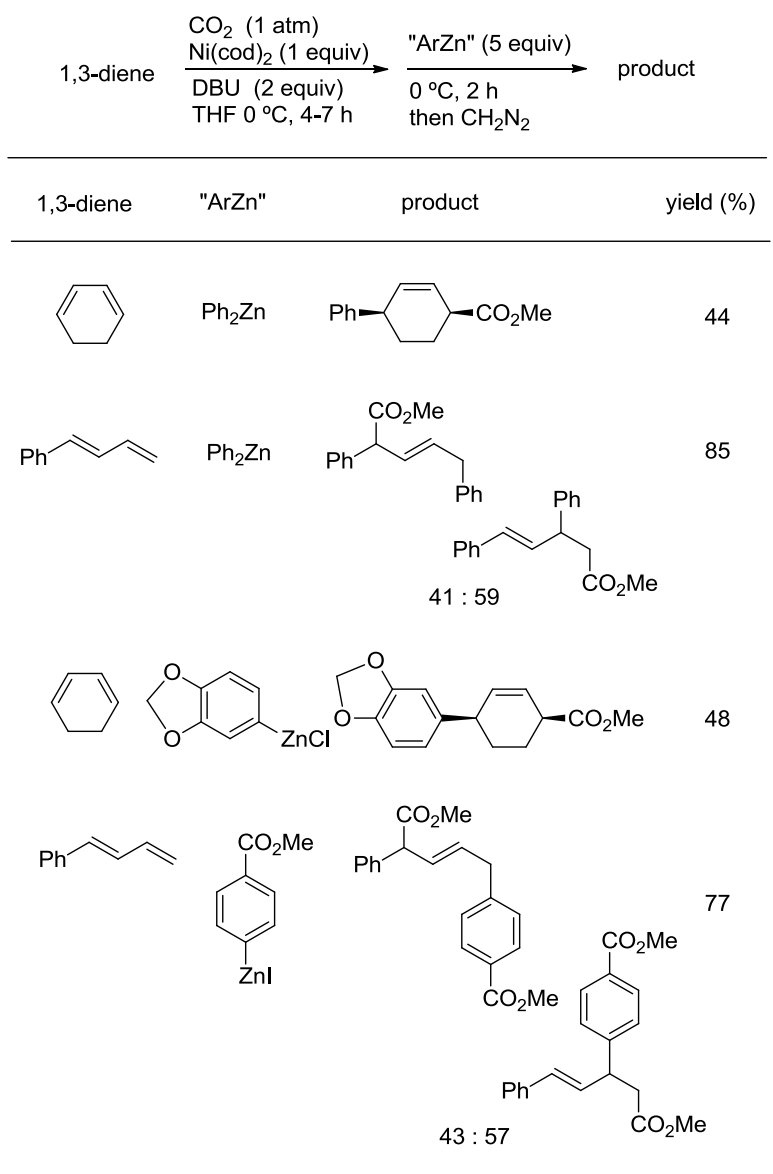

and then further with 5 equiv of $\mathrm{Me}_{2} \mathrm{Zn}, 1,4$-double-carboxylation products were afforded in good yields (Table 1). ${ }^{13 a}$ Although the mechanism of the stoichiometric reaction was not clear, the two $\mathrm{CO}_{2}$ molecules, but no Me moieties, were incorporated in the 5 products. In contrast, when aryl zinc reagents (ArZn) instead of $\mathrm{Me}_{2} \mathrm{Zn}$ were employed in the similar stoichiometric reaction, arylative mono-carboxylation proceeded (Table 2). ${ }^{13 \mathrm{a}}$ Furthermore, by using bis-1,3-dienes as the substrates, the catalytic reaction provided ring-closing carboxylated products 10 regio- and stereoselectively in high yields (Scheme 7a). ${ }^{13 \mathrm{~b}}$ The asymmetric carbonylative cyclization were realized under similar reaction conditions with chiral phosphine ligands (Scheme 7b). ${ }^{13 \mathrm{c}}$ Mori et al. also found Ni-catalyzed double-carboxylation of trimethylsilylallene with $\mathrm{CO}_{2}{ }^{13 \mathrm{~d}}$ and Ni-promoted 15 carboxylation/cyclization cascade reaction of allenyl aldehydes. $^{13 \mathrm{e}}$ In the former case, the silyl moieties were indispensable for the double carboxylation.

Iwasawa et al. reported hydrocarboxylation of allenes with $\mathrm{CO}_{2}$ catalyzed by $\mathrm{Pd}$ pincer catalyst (Table 3). ${ }^{14 a} \mathrm{AlEt}_{3}$ was 20 employed as a reducing agent and a hydrido source after the $\beta$ hydride elimination of the resulting ethyl palladium intermediate (Scheme 8). With a similar Pd catalyst system, one-to-one coupling of 1,3-dienes with $\mathrm{CO}_{2}$ occurred (Table 4). ${ }^{14 \mathrm{~b}}$ (a)
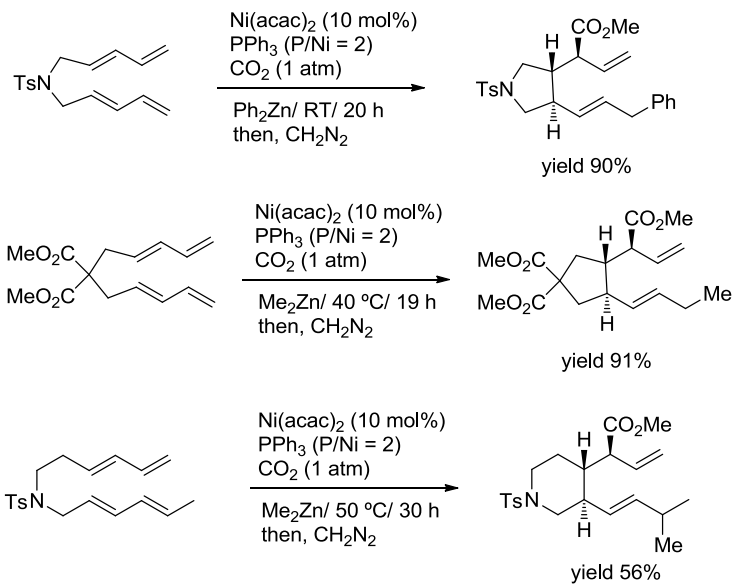

(b)
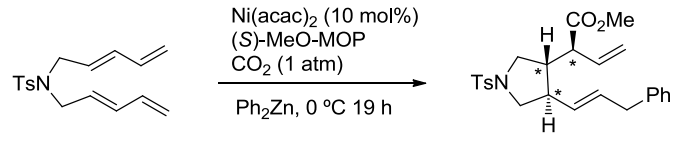

yield $90 \%$, ee $95 \%$
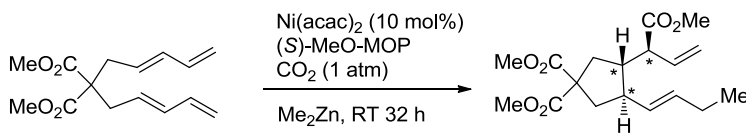

(S)-MeO-MOP

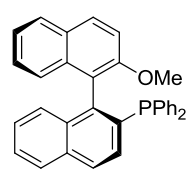

Scheme 7 Nickel-catalyzed ring-closing carboxylation of bis1,3-dienes

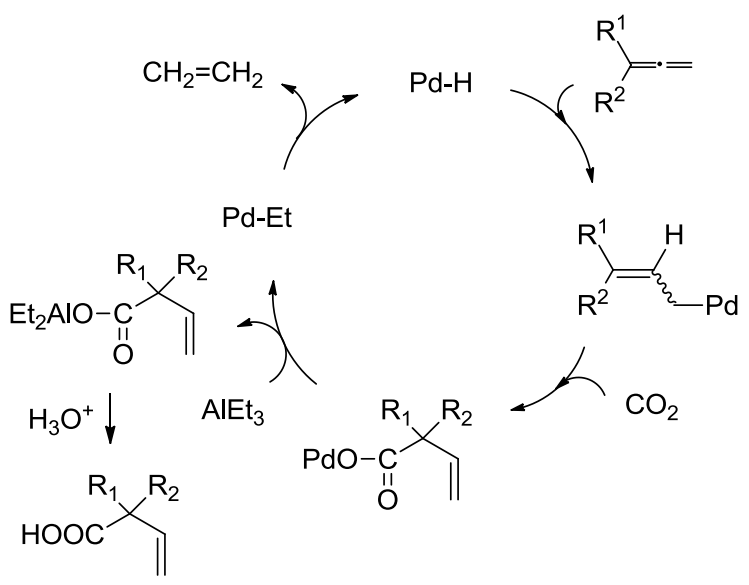

Scheme 8 Catalytic cycle of Pd-catalyzed hydrocarboxylation of allenes 
Table 3 Pd-catalyzed hydrocarboxylation of allenes

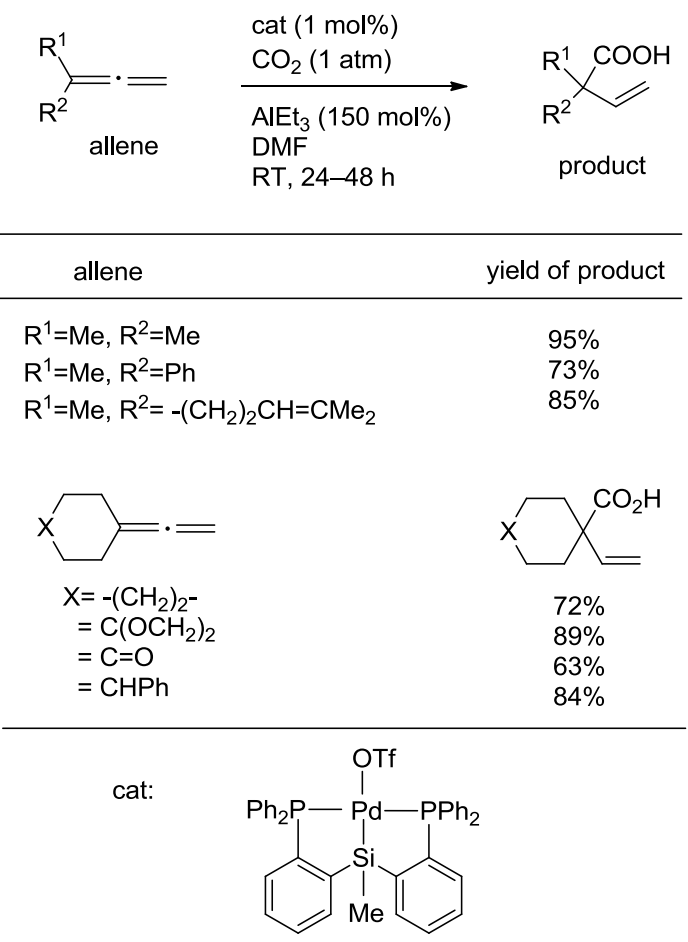

Table 4 Pd-catalyzed hydrocarboxylation of 1,3-diene: one-toone coupling with $\mathrm{CO}_{2}$

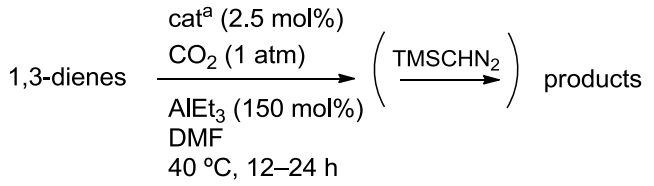

yields (\%)

a The same Pd complex in Table 3 was used as a catalyst

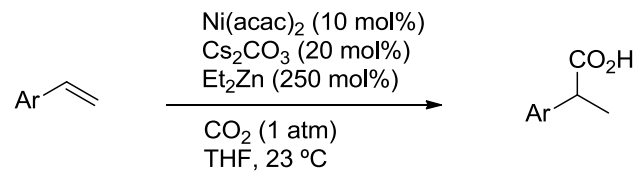

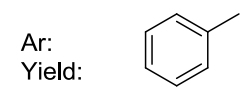

$56 \%$

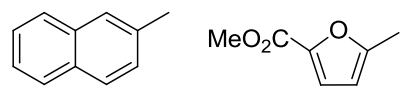

$60 \%$

$66 \%$

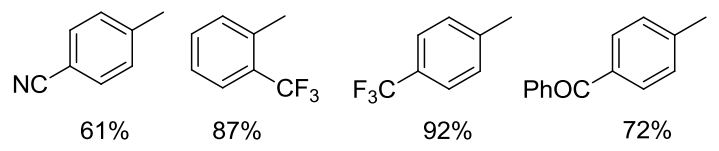

Scheme 9 Ni-catalyzed reductive carboxylation of styrenes using $\mathrm{CO}_{2}$ (a)

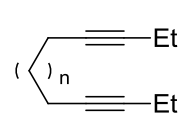

(b)<smiles>[R]C#CCC([R])([R])CC#[R]</smiles>
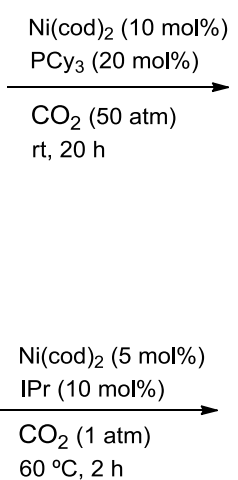<smiles>[R]c1oc(=O)c([R])c2c1CC([R])([R])C2</smiles>

$R^{1}=\mathrm{CO}_{2} \mathrm{Me}, \mathrm{R}^{2}=\mathrm{Me}: 93 \%$ $\mathrm{R}^{1}=\mathrm{CO}_{2} \mathrm{Me}, \mathrm{R}^{2}=i \mathrm{Pr}: 86 \%$ $\mathrm{R}^{1}=\mathrm{PhCH}_{2} \mathrm{OCH}_{2}, \mathrm{R}^{2}=\mathrm{Me}: 93 \%$
Scheme 10 Carboxylation of $\alpha, \omega$-diynes with $\mathrm{CO}_{2}$

As for alkenes, Rovis et al. found reductive carboxylation of styrene derivatives with $\mathrm{Et}_{2} \mathrm{Zn}$ and $\mathrm{CO}_{2}$ (Scheme 9). ${ }^{15}$ They proposed an insertion on $\mathrm{Ni}-\mathrm{H}$ into carbon-carbon double bonds of styrenes followed by insertion of $\mathrm{CO}_{2}$, rather than the Hoberg's 5 metallacycle shown in Scheme 2.

\subsection{Carboxylation of alkynes}

Pioneering works for catalytic carboxylation of alkynes were carried out by Inoue et al. as shown in Scheme 3b,c. ${ }^{8 b, c}$ Tsuda and ${ }_{10}$ Saegusa found that the reactions of $\alpha, \omega$-diynes under pressurized $\mathrm{CO}_{2}(50 \mathrm{~atm})$ in the presence of Ni-phosphane catalyst proceeded smoothly and afforded bicyclic $\alpha$-pyrones in good yields (Scheme 10a). ${ }^{16 a}$ In this transformation, IPr ligand in place of phosphanes is much more effective and provided the similar 15 carboxylated products in high yields under 1 atm of $\mathrm{CO}_{2}(\mathrm{Scheme}$ $10 \mathrm{~b}){ }^{16 \mathrm{~b}}$

On the other hand, Yamamoto et al. reported that terminal alkynes reacted with 1 equiv of $\mathrm{Ni}(\operatorname{cod})_{2}$ and 2 equiv of dbu 
(a)
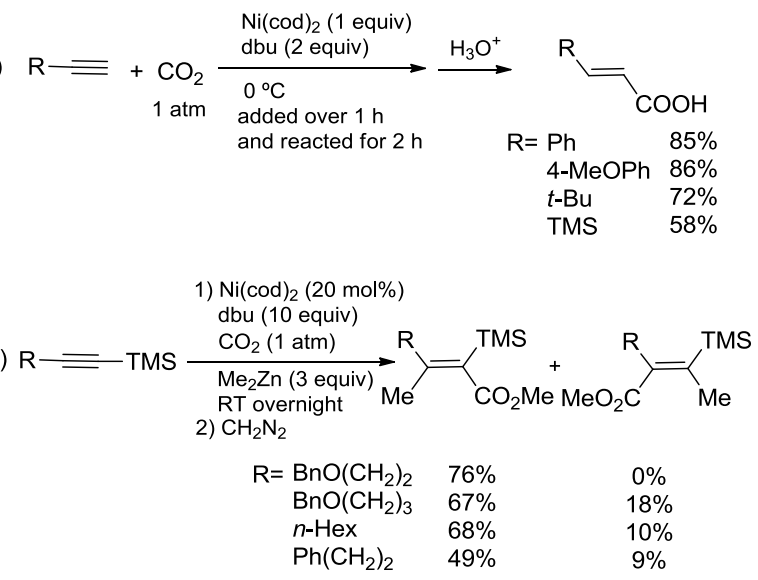

Scheme 11 Carboxylation of terminal and TMS acetylenes

under $\mathrm{CO}_{2}(1 \mathrm{~atm})$ at $0{ }^{\circ} \mathrm{C}$ in a highly regio- and chemoselective manner (Scheme 11a). ${ }^{17 \mathrm{a}}$ Similar carboxylation reaction with 1 equiv of $\mathrm{Ni}(\mathrm{cod})_{2}$ was also carried out using bidentate amidine ligands. ${ }^{17 \mathrm{~b}}$ When alkyl or aryl zinc reagent was added into the 5 Yamaoto's system, alkylative and arylative carboxylation of alkynes proceeded (Table 5). ${ }^{17 \mathrm{c}, \mathrm{e}}$ Interestingly, BuZn reagent afforded the butylated product (entry 3), while EtZn gave hydrocarboxylated product via $\beta$-hydride elimination (entry 4 ). This alkylative carboxylation could be carried out catalytically 10 when trimethylsilyl acetylenes were employed as substrates

Table 5 Carboxylation of alkyne with $\mathrm{Ni}(\operatorname{cod})_{2}$ and organozinc reagents

\begin{tabular}{l} 
entry "RZn" \\
1 \\
\hline
\end{tabular}

${ }^{a}$ Isolated yield based on $\mathrm{Ni}(\operatorname{cod})_{2}$

$\mathrm{CO}_{2} \mathrm{H}$ in $78 \%$ yield
Table $6 \mathrm{Cu}$-catalyzed hydrocarboxylation of alkyne using $\mathrm{CO}_{2}$ and hydrosilanes

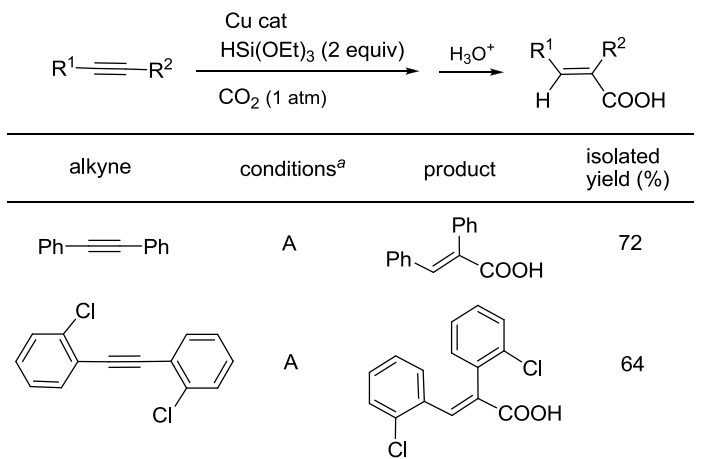<smiles>N#Cc1cccc(C#Cc2cccc(C=C(C(=O)O)c3cccc(C#N)c3)c2)c1</smiles><smiles>CCCCOC(=O)c1ccc(/C=C(/C(=O)OCCC)c2ccc(C(=O)OCC)cc2)cc1</smiles>
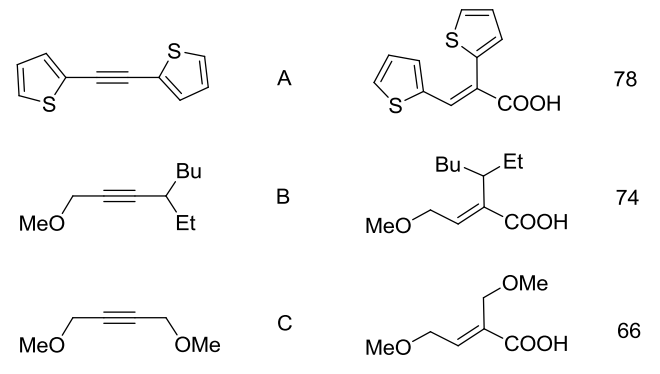

${ }^{a}$ Conditions A: IMesCuF (1-2 mol\%) in 1,4-dioxane at $100^{\circ} \mathrm{C}$ for $12 \mathrm{~h}$. Conditions B: ClIPrCuF $(2.5 \mathrm{~mol} \%)$ in hexane at $70^{\circ} \mathrm{C}$ for 14 h. Conditions C: $\operatorname{IPrCuF}(2.5 \mathrm{~mol} \%)$ in 1,4 -dioxane at $100{ }^{\circ} \mathrm{C}$ for $14 \mathrm{~h}$.

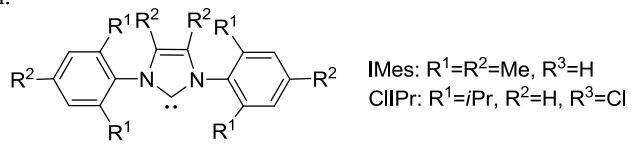

(Scheme 11b). ${ }^{17 \mathrm{~d}}$

In order to utilize $\mathrm{CO}_{2}$ in $\mathrm{C}-\mathrm{C}$ bond formations, reducing reagents have been indispensable in the reactions. To date, highly reactive and pyrophoric reagents such as $\mathrm{Et}_{2} \mathrm{Zn}^{9,15,17 \mathrm{a}, \mathrm{d}, \mathrm{e}}$ and ${ }_{15} \mathrm{Et}_{3} \mathrm{Al}^{14}$ were employed in stoichiometric and catalytic reactions. We recently reported that hydrosilanes, more mild and easy-tohandle reducing reagents, can be used in $\mathrm{Cu}$ catalyzed hydrocarboxylation of alkynes. ${ }^{18 a}$ Various alkynes were hydrocarboxylated efficiently using $\mathrm{HSi}(\mathrm{OEt})_{3}$ in good yields 20 (Table 6). In the reactions, $\mathrm{HSi}(\mathrm{OEt})_{3}$ could be replaced with polymethylhydrosiloxane (PMHS), which is a cheap by-product of the silicon industry. Ma et al. found that the same reaction proceeded with $\mathrm{Ni}(\mathrm{cod})_{2}-\mathrm{CsF}$ as a catalyst and $\mathrm{Et}_{2} \mathrm{Zn}$ as a reducing reagent. ${ }^{18 \mathrm{~b}} \mathrm{Ma}$ also reported methylative carboxylation 25 of homopropargylic alcohols. ${ }^{18 \mathrm{c}}$

Inoue et al. found that terminal alkynes reacted with 
Table 7 Au-catalyzed carboxylation of aromatic C-H bonds

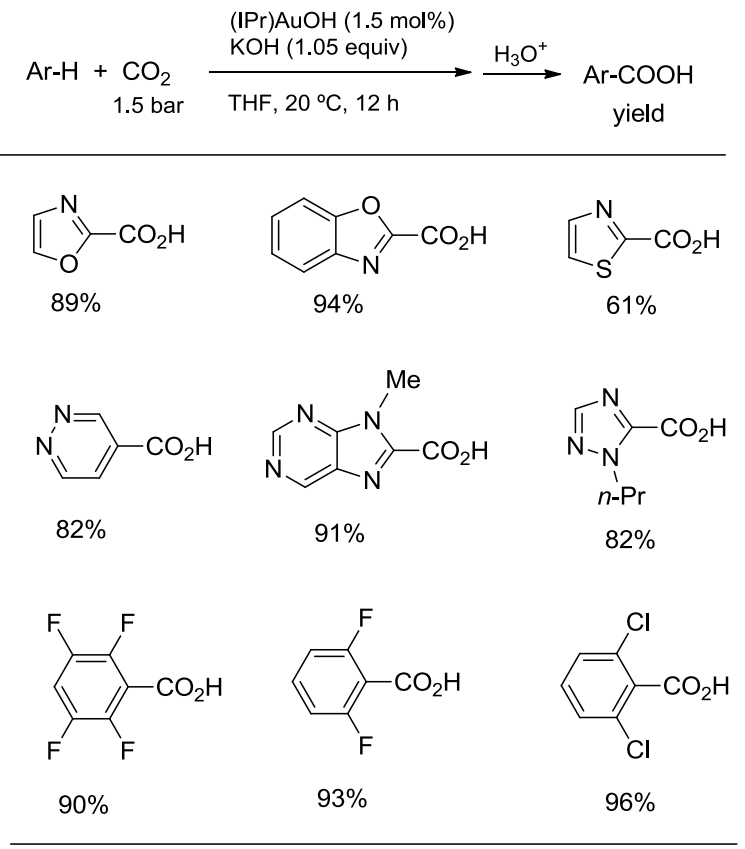

(a)

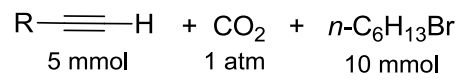

Cul $(0.2 \mathrm{mmol})$

$\mathrm{K}_{2} \mathrm{CO}_{3}(30 \mathrm{mmol})$

in DMA

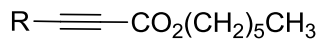

$100^{\circ} \mathrm{C}, 4 \mathrm{~h}$

$$
\begin{aligned}
& \text { yield: } \mathrm{R}=\mathrm{Ph} \quad 89 \% \\
& p-\mathrm{CH}_{3} \mathrm{C}_{6} \mathrm{H}_{4} \quad 79 \% \\
& n-\mathrm{C}_{6} \mathrm{H}_{13} \quad 78 \%
\end{aligned}
$$

(b)

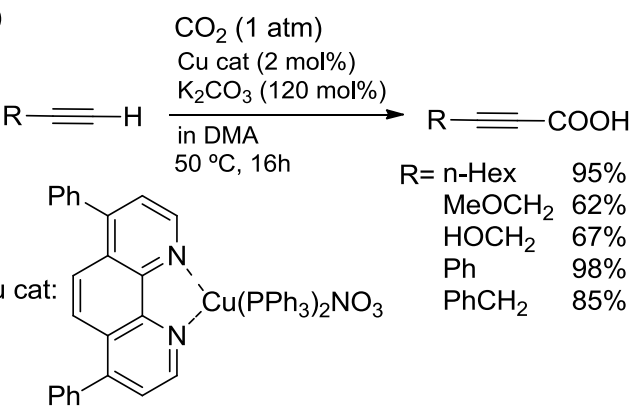

Scheme 12 Carboxylation of terminal alkynes with $\mathrm{CO}_{2}$ with and without bromoalkanes

bromoalkanes under $\mathrm{CO}_{2}$ in the presence of a catalytic amount of CuI. ${ }^{19 a}$ Insertion of $\mathrm{CO}_{2}$ into the acetylenic $\mathrm{C}-\mathrm{H}$ bonds to give alkyl 2-alkynoates at $100{ }^{\circ} \mathrm{C}$ in good yields (Scheme 12a). $\mathrm{CuBr}$, $\mathrm{AgI}$, or $\mathrm{AgNO}_{3}$ can be utilized as the catalyst successfully. This 5 reaction was applied to one-pot synthesis of arylnaphthalene lactones. ${ }^{19 \mathrm{~b}}$ Recently, IPrCuCl was found to be a more efficient and the reaction proceeded even at lower temperature $\left(60^{\circ} \mathrm{C}\right) .{ }^{19 \mathrm{c}}$ Furthermore, insertion of $\mathrm{CO}_{2}$ into the $\mathrm{C}-\mathrm{H}$ bond proceeded without bromoalkanes in the presence of a $\mathrm{Cu}^{20 \mathrm{a}, \mathrm{b}}$ (Scheme 12b) 10 or $\mathrm{Ag}^{20 \mathrm{c}}$ catalyst. The same reactions could be carried out without the transition metal catalysts at $120-160^{\circ} \mathrm{C}$, but 2 equiv of $\mathrm{Cs}_{2} \mathrm{CO}_{3}$ was indispensable. ${ }^{20 \mathrm{~d}}$

\subsection{Carboxylation of aryl halides}

15 As mentioned earlier, the carboxylation reactions of arylzinc (section 2.1) and arylboronic esters (section 2.2) with $\mathrm{CO}_{2}$ have been studied intensively, since in these reactions various functionalities that are compatible unlike with Grignard reagents. However, these zinc and boron compounds must be prepared 20 from the corresponding aryl halides prior to the catalytic reactions. Thus, the direct carboxylation of the parent aryl halides is most desirable as this is a more straightforward transformation.

The catalytic carboxylation of aryl halides employing $\mathrm{CO}_{2}$ was first developed as electrochemical reactions in the presence of ${ }_{25}$ nickel $^{21 \mathrm{a}-\mathrm{c}}$ and palladium catalysts (Scheme 13a). ${ }^{21 \mathrm{~d}, \mathrm{e}}$ Unfortunately, these were not efficient synthetic methods, and the scope of possible substrates was quite restricted. Later, the nonelectrochemical carboxylation of aryl bromides and chlorides using $\mathrm{CO}_{2}$ was carried out in the presence of stoichiometric 30 amounts of $\mathrm{Ni}(0)$ complexes and 2,2'-bipyridine (bpy) (Scheme 13b). ${ }^{22 a}$ Recently, the carboxylation of aryl bromides employing $\mathrm{CO}_{2}$ was performed catalytically using a palladium complex as the catalyst. ${ }^{22 \mathrm{~b}}$

(a)

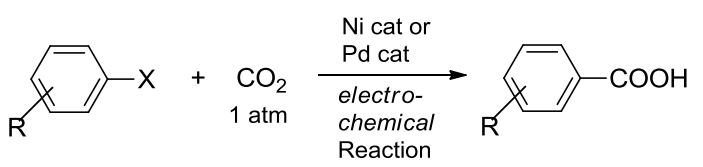

(b)

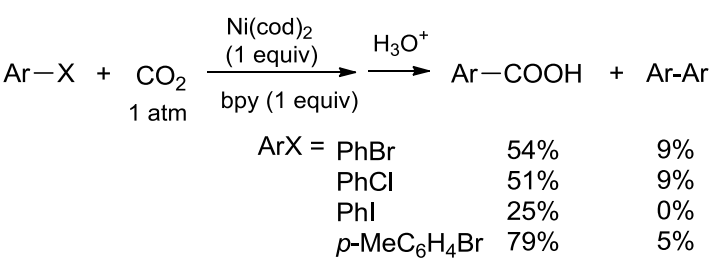

(c)

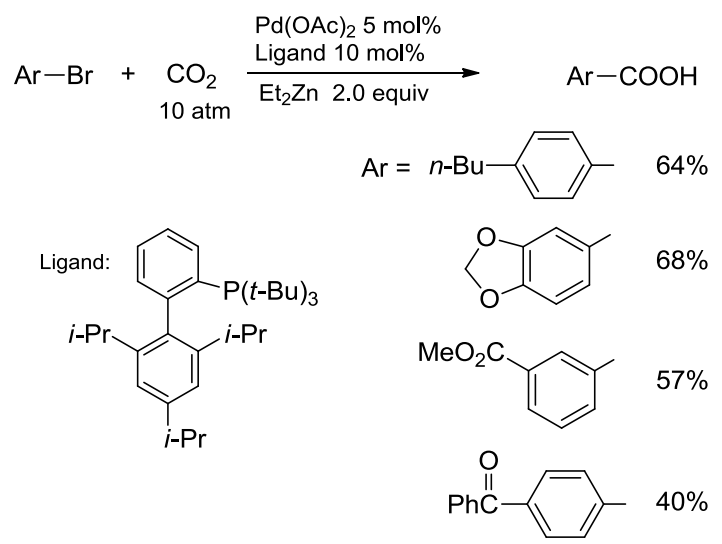

Scheme 13 Carboxylation of aryl halides with $\mathrm{CO}_{2}$ 


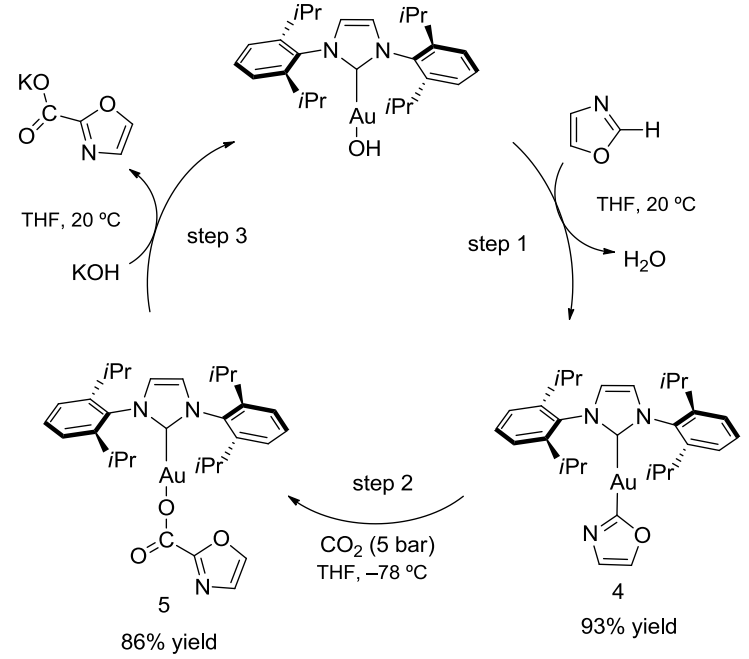

Scheme 14 Stoichiometric reactions relevant to the catalytic cycle

\subsection{Carboxylation of arenes having acidic $\mathrm{C}-\mathrm{H}$ bonds}

The Kolbe-Schmitt salicylic acid synthesis from sodium phenolate and $\mathrm{CO}_{2}$ is an early example of carboxylation of $\mathrm{C}-\mathrm{H}$ bonds. Such direct carboxylation of $\mathrm{C}-\mathrm{H}$ bonds must be more 5 sustainable transformations. Recently, Nolan et al. reported that (IPr)AuOH can perform the activation of $\mathrm{C}-\mathrm{H}$ bonds of electrondeficient arenes. ${ }^{23 \mathrm{a}}$ They found that the same $\mathrm{Au}(\mathrm{I})$ complex is very active for carboxylation of aromatic acidic $\mathrm{C}-\mathrm{H}$ bonds ( $\mathrm{pKa}$ values < 30) with $\mathrm{CO}_{2}$ (Table 7). ${ }^{23 \mathrm{~b}}$ The possible catalytic cycle 10 for the present $\mathrm{C}-\mathrm{H}$ carboxylation (Scheme 14) is similar to the mechanism postulated for $\mathrm{Cu}(\mathrm{I})$ catalyzed carboxylation of organoboronic esters (Scheme 5). The authors confirmed the mechanism by stoichiometric reactions (Scheme 14). Protonolysis of (IPr)AuOH by 1 equiv of oxazole gave the 15 intermediate 4, which was isolated in $93 \%$ yield (step 1). Reaction of 4 by saturating the solution with $\mathrm{CO}_{2}$ at $-100{ }^{\circ} \mathrm{C}$ afforded carboxylate complex $\mathbf{5}$ in $86 \%$ isolated yield (step 2). Finally, (IPr) $\mathrm{AuOH}$ was regenerated upon metathesis of 5 with 1 equiv of $\mathrm{KOH}$ with precipitation of potassium oxazole-220 carboxylate (step 3). Hou et al. ${ }^{23 c}$ and Nolan and coworkers ${ }^{23 \mathrm{~d}}$ independently reported that $\mathrm{Cu}$ catalysts are active as catalysts in the carboxylation reaction of the acidic $\mathrm{C}-\mathrm{H}$ bonds (Table 8). ${ }^{23 \mathrm{c}}$ Hou isolated catalytic intermediates (arylcopper and copper carboxylate) in a stoichiometric reaction and determined the 25 structures by X-ray crystallographic analysis. ${ }^{23 c}$ However, these $\mathrm{C}-\mathrm{H}$ carboxylations could proceed with only a base $\left(\mathrm{Cs}_{2} \mathrm{CO}_{3}\right.$ is most suitable) at $125^{\circ} \mathrm{C}$. ${ }^{23 \mathrm{e}}$ Iwasawa et al. found the first $\mathrm{C}-\mathrm{H}$ carboxylation with $\mathrm{CO}_{2}$ via chelation-assisted $\mathrm{C}-\mathrm{H}$ activation. Various 2-arylpyridines and 1-arylpyrazoles afforded 30 carboxylated products in the presence of a $\mathrm{Rh}$ catalyst and a stoichiometric amount of $\mathrm{AlMe}_{2}(\mathrm{OMe})$ (Table 9).
Table 8 Cu-catalyzed carboxylation of aromatic $\mathrm{C}-\mathrm{H}$ bonds
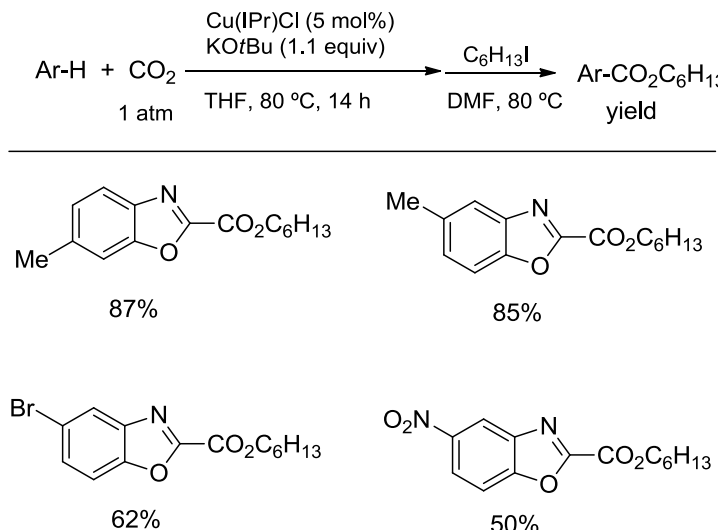<smiles>O=C(Oc1ccccc1)c1nc2cc([N+](=O)[O-])ccc2o1</smiles><smiles>CCOC(=O)c1nc2cc(-c3ccc(C#N)cc3)ccc2o1</smiles>

Table 9 Rh-catalyzed direct carboxylation of arenes via chelation-assisted $\mathrm{C}-\mathrm{H}$ bond activation

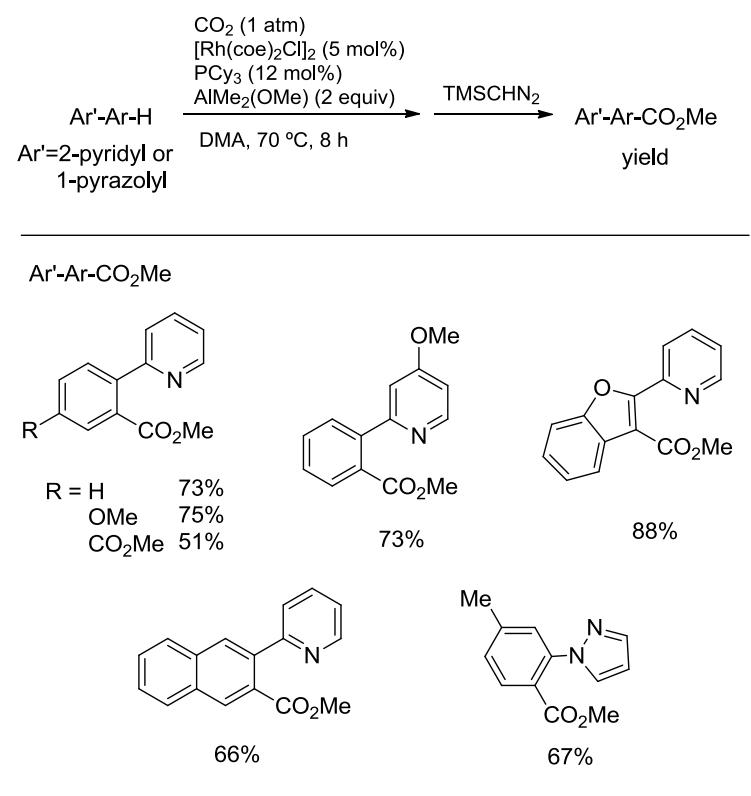

\section{${ }_{35}$ Conclusions}

Carbon dioxide $\left(\mathrm{CO}_{2}\right)$ can be utilized in carbon-carbon bond forming reactions with the aid of transition-metal catalysts. Organozinc compounds usually do not react with $\mathrm{CO}_{2}$ without a transition-metal catalyst. and $\mathrm{Ni}$ and $\mathrm{Pd}$ catalysts are active to 
afford the corresponding carboxylic acids. Organoboronic esters are also useful substrates which are reacted with $\mathrm{CO}_{2}$ to provide the carboxylic acids in the presence of $\mathrm{Rh}$ and $\mathrm{Cu}$ catalysts. In the $\mathrm{Cu}$-catalyzed reaction, aryl- $\mathrm{Cu}$ or $\mathrm{ArCOOCu}$ intermediates were 5 isolated and fully characterized. Dienes, alkenes, and alkynes were efficiently reacted with $\mathrm{CO}_{2}$ in the presence of $\mathrm{Ni}, \mathrm{Pd}$, and $\mathrm{Cu}$ catalysts. Usually, highly reactive and pyrophoric reducing reagents such as $\mathrm{Et}_{2} \mathrm{Zn}$ and $\mathrm{Et}_{3} \mathrm{Al}$ are indispensable in the reactions. Recently, easy-to-handle hydrosilanes such as ${ }_{10} \mathrm{HSi}(\mathrm{OEt})_{3}$ and polymethylhydrosiloxane (PMHS) can be employed with a $\mathrm{Cu}$ catalyst. Carboxylation of aryl halides and arenes having acidic $\mathrm{C}-\mathrm{H}$ bonds are realized.

\section{Notes and references}

Department of Energy and Hydrocarbon Chemistry, Graduate School of 15 Engineering, Kyoto University, Kyoto, 615-8510, Japan. Fax:+81-75383-2514; Tel:+81-75-383-2515; E-mail: ytsuji@scl.kyoto-u.ac.jp

1 Carbon Dioxide as a Chemical Feedstock, ed. M. Aresta, WileyVHC, Weinheim, 2010.

202 (a) M. Cokoja, C. Bruckmeier, B. Rieger, W. A. Herrmann, F. E. Kühn, Angew. Chem. Int. Ed., 2011, 50, 8510-8537. (b) K. Huang, C.-L. Sun, Z.-J. Shi, Chem. Soc. Rev., 2011, 40, 2435-2452. (c) S. N. Riduan, Y. Zhang, Dalton Trans., 2010, 39, 3347-3357. (d) T. Sakakura, J.-C. Choi, H. Yasuda, Chem. Rev., 2007, 107, 23652387. (e) D. J. Darensbourg, Chem. Rev., 2007, 107, 2388-2410. (f) M. Aresta, A. Dibenedetto, Dalton Trans., 2007, 2975- 2992. (g) C. M. Rayner, Org. Process Res. Dev., 2007, 11, 121-132. (h) J. Louie, Curr. Org. Chem., 2005, 9, 605-623. (i) A. Behr, Angew. Chem. Int. Ed., 1988, 27, 661-678. (j) P. Braunstein, D. Matt, D. Nobel, Chem. 30 Rev., 1988, 88, 747-764. (k) D. Walther, Coordin. Chem. Rev., 1987, 79, 135-174.

3 Recent results ${ }^{3 \mathrm{a}-\mathrm{c}}$ and reviews ${ }^{3 \mathrm{~d}-\mathrm{g}}$ for carbon-oxygen bond forming reactions, see: (a) K. Nakano, S. Hashimoto, M. Nakamura, T. Kamada, K. Nozaki, Angew. Chem. Int. Ed., 2011, 50, 4868- 4871. (b) S. Kikuchi, S. Yoshida, Y. Sugawara, W. Yamada, H.-M. Cheng, K. Fukui, K. Sekine, I. Iwakura, T. Ikeno, T. Yamada, Bull. Chem. Soc. Jpn., 2011, 84, 698- 717. (c) S. Yoshida, K. Fukui, S. Kikuchi, T. Yamada, J. Am. Chem. Soc., 2010, 132, 4072- 4073. (d) M. R. Kember, A. Buchard, C. K. Williams, Chem. Commun, 2011, 47, 141-163. (e) W. Clegg, R. W. Harrington, M. North, R. Pasquale, Chem. Eur. J. 2010, 16, 6828-6843. (f) A. Decortes, A. M. Castilla, A. W. Kleij, Angew. Chem. Int. Ed., 2010, 49, 9822-9837. (g) T. Sakakura, K. Kohno, Chem. Commun. 2009, 1312-1330.

4 Recent results ${ }^{4 a-d}$ and reviews ${ }^{4-h}$ for carbon-hydrogen bond forming

45 reactions, see: (a) C. A. Huff, M. S. Sanford, J. Am. Chem. Soc., 2011, 133, 18122- 18125. (b) L. C. Grabow, M. Mavrikakis, ACS Catal., 2011, 1, 365- 384. (c) S. N. Riduan, Y. Zhang, J. Y. Ying, Angew. Chem. Int. Ed., 2009, 48, 3322- 3325. (d) R. Tanaka, M. Yamashita, K. Nozaki, J. Am. Chem. Soc., 2009, 131, 14168-14169. (e) C. Federsel, R. Jackstell, M. Beller, Angew. Chem. Int. Ed., 2010, 49, 6254-6257. (f) P. G. Jessop, F. Joó, C.-C. Tai, Coordin. Chem. Rev., 2004, 248, 2425-2442. (g) W. Leitner, Angew. Chem. Int. Ed., 1995, 34, 2207-2221. (h) P. G. Jessop, T. Ikariya, R. Noyori, Chem. Rev., 1995, 95, 259-272.

555 M. Aresta, C. F. Nobile, J. Chem. Soc., Chem. Commun., 1975, 636637.

6 (a) G. Burkhart, H. Hoberg, Angew. Chem. Int. Ed., 1982, 21, 76. (b) H. Hoberg, Y. Peres, C. Krüger, Y.-H. Tsay, Angew. Chem. Int. Ed., 1987, 26, 771-773.

607 (a) X. Yin, J. R. Moss, Coordin. Chem. Rev., 1999, 181, 27-59. (b) D H. Gibson, Chem. Rev., 1996, 96, 2063-2095. (c) D. A. Palmer, Chem. Rev., 1983, 83, 651-731.

8 (a) Y. Sasaki, Y. Inoue, H. Hashimoto, J. Chem. Soc., Chem. Commun., 1976, 605-606. (b) Y. Inoue, Y. Itoh, H. Hashimoto, Chem. Lett., 1977, 855-856. (c) Y. Inoue, Y. Ito, H. Hashimoto,
Chem. Lett., 1978, 633-634. (d) Y. Inoue, T. Hibi, M. Satake, H. Hashimoto, J. Chem. Soc., Chem. Commun., 1979, 982.

9 (a) H. Ochiai, M. Jang, K. Hirano, H. Yorimitsu, K. Oshima, Org. Lett., 2008, 10, 2681-2683. (b) C. S. Yeung, V. M. Dong, J. Am. Chem. Soc., 2008, 130, 7826-7827. (c) K. Kobayashi, Y. Kondo, Org. Chem., 2009, 11, 2035-2037.

10 (a) K. Ukai, M. Aoki, J. Takaya, N. Iwasawa, J. Am. Chem. Soc., 2006, 128, 8706-8707. (b) T. Ohishi, M. Nishiura, Z. Hou, Angew. Chem. Int. Ed., 2008, 47, 5792-5795. (c) L. Dang, Z. Lin, T. B. Marder, Organometallics, 2010, 29, 917-927. (d) J. Takaya, S. Tadami, K. Ukai, N. Iwasawa, Org. Lett., 2008, 10, 2697-2700.

11 (a) T. Tsuda, K. Ueda, T. Saegusa, J. Chem. Soc., Chem. Commun., 1974,380-381. (b) G. W. Ebert, W. L. Juda, R. H. Kosakowski, B. Ma, L. Dong, K. E. Cummings, M. V. B. Phelps, A. E. Mostafa, J. Luo, J. Org. Chem., 2005, 70, 4314-4317.

12 (a) H. Ohmiya, M. Tanabe, M. Sawamura, Org. Lett., 2011, 13, 1086-1088. (b) T. Ohishi, L. Zhang, M. Nishiura, Z. Hou, Angew. Chem. Int. Ed., 2011, 50, 8114-8117.

13 (a) M. Takimoto, M. Mori, J. Am. Chem. Soc., 2001, 123, 2895 85 2896. (b) M. Takimoto, M. Mori, J. Am. Chem. Soc., 2002, 124, 10008-10009. (c) M. Takimoto, Y. Nakamura, K. Kimura, M. Mori, J. Am. Chem. Soc., 2004, 126, 5956-5956. (d) M. Takimoto, M. Kawamura, M. Mori, Y. Sato, Synlett, 2005, 2019-2022. (e) M. Takimoto, M. Kawamura, M. Mori, Y. Sato, Synlett, 2011, $1423-$ 1426.

14 (a) J. Takaya, N. Iwasawa, J. Am. Chem. Soc., 2008, 130, 15254 15255. (b) J. Takaya, K. Sasano, N. Iwasawa, Org. Lett., 2011, 13, 1698-1701.

15 C. M. Williams, J. B. Johnson, T. Rovis, J. Am. Chen. Soc., 2008, 130, 14936-14937.

16 (a) T. Tsuda, S. Morikawa, R. Sumiya, T. Saegusa, J. Org. Chem., 1988, 53, 3140-3145. (b) J. Louie, J. E. Gibby, M. V. Farnworth, T. N. Tekavec, J. Am. Chem. Soc., 2002, 124, 15188-15189.

17 (a) S. Saito, S. Nakagawa, T. Koizumi, K. Hirayama, Y. Yamamoto, 100 J. Org. Chem., 1999, 64, 3975-3978. (b) M. Aoki, M. Kaneko, S Izumi, K. Ukai, N. Iwasawa, Chem. Commun., 2004, 2568-2569. (c) M. Takimoto, K. Shimizu, M. Mori, Org. Lett., 2001, 3, 33453347. (d) K. Shimizu, M. Takimoto, Y. Sato, M. Mori, Org. Lett., 2005, 7, 195-197. (e) M. Mori, Eur. J. Org. Chem., 2007, 49814993.

18 (a) T. Fujihara, T. Xu, K. Semba, J. Terao, Y. Tsuji, Angew. Chem Int. Ed., 2011, 50, 523-527. (b) S. Li, W. Yuan, S. Ma, Angew. Chem. Int. Ed., 2011, 50, 2578-2582. (c) S. Li, S. Ma, Org. Lett., 2011, 13, 6046-6049.

11019 (a) Y. Fukue, S. Oi, Y. Inoue, J. Chem. Soc., Chem. Commun., 1994, 2091. (b) N. Eghbali, J. Eddy, P. T. Anastas, J. Org. Chem., 2008, 73, 6932-6935. (c) W.-Z. Zhang, W.-J. Li, X. Zhang, H. Zhou, X.-B. Lu, Org. Lett., 2010, 12, 4748-4751.

20 (a) L. J. Gooßen, N. Rodríguez, F. Manjolinho, P. P. Lange, $A d v$. Synth. Catal., 2010, 352, 2913-2917. (b) D. Yu, Y. Zhang, Proc. Natl. Acad. Sci. USA, 2010, 107, 20184-20189. (c) X. Zhang, W.-Z. Zhang, X. Ren, L.-L. Zhang, X.-B. Lu, Org. Lett., 2011, 13, 2402 2405. (d) Y. Dingyi, Z. Yugen, Green Chem., 2011, 13, 1275-1279.

21 (a) M. Troupel, Y. Rollin, J. Perichon, New J. Chem. 1981, 5, 621625. (b) J.-F. Fauvarque, C. Chevrot, A. Jutand, M. Francois, $J$. Organomet. Chem. 1984, 264, 273-281. (c) C. Amatore, A. Jutand, J. Am. Chem. Soc. 1991, 113, 2819-2825. (d) S. Torii, H. Tanaka, T. Hamatani, K. Morisaki, A. Jutand, F. Pfluger, J.-F. Fauvarque, Chem. Lett. 1986, 169-172. (e) C. Amatore, A. Jutand, F. Khalil, M. F. Nielsen, J. Am. Chem. Soc. 1992, 114, 7076-7085.

22 (a) K. Osakada, R. Sato, T. Yamamoto, Organometallics 1994, 13, 4645-4647.(b) A. Correa, R. Martín, J. Am. Chem. Soc. 2009, 131, 15974-15975.

23 (a) S. Gaillard, A. M. Z. Slawin, S. P. Nolan, Chem. Commun., 2010, 46, 2742-2744. (b) I. I. F. Boogaerts, S. P. Nolan, J. Am. Chem. Soc. 2010, 132, 8858-8859. (c) L. Zang, J. Cheng, T. Ohishi, Z. Hou, Angew. Chem., Int. Ed. 2010, 49, 8670-8673. (d) I. I. F. Boogaerts, G. C. Fortman, M. R. L. Furst, C. S. J. Cazin, S. P Nolan, Angew. Chem., Int. Ed. 2010, 49, 8674-8677. (e) O Vechorkin, N. Hirt, X. Hu, Org. Lett., 2010, 12, 3567-3569. (f) H. Mizuno, J. Takaya, N. Iwasawa, J. Am. Chem. Soc. 2011, 133, $1251-1253$ 


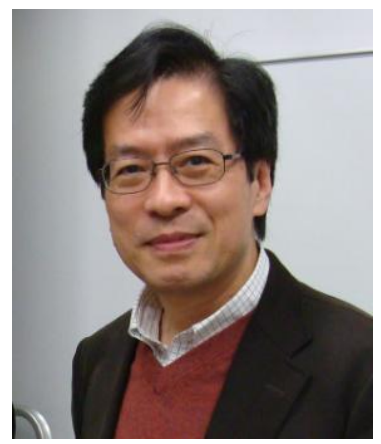

Yasushi Tsuji was born in Japan (Osaka) in 1953. He received his Bachelor (1976), Master (1978), and Doctor of Engineering (1981) form Kyoto University under the supervision of Professor 5 Yoshinobu Takegami. He was appointed as a Research Associate at the Faculty of Engineering, Kyoto University in 1981. He spent the year 1986 to 1987 as a Postdoctoral Fellow at Northwestern University with Professor Tobin J. Marks. He was an Associate Professor at the Faculty of Engineering, Gifu University from 101989 to 1998, then at the Institute for Molecular Science from April to September in 1998. He was promoted to a Full Professor at the Catalysis Research Center, Hokkaido University in 1998. In 2006, he moved back to Kyoto and has been a Full Professor at the Faculty of Engineering, Kyoto University. He received the ${ }_{15}$ Chemical Society of Japan Award for Creative Work in 2002. He has been interested in the development of new catalysis by transition -metal complexes.

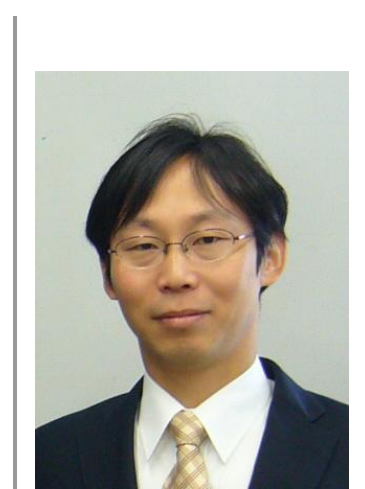

${ }_{20}$ Tetsuaki Fujihara was born in Japan (Shiga) in 1973. He received his Bachelor of Science from Shizuoka University in 1996. He moved to Hokkaido University, where he pursued his Master of Science (1998). He received his Ph.D. degree in 2001 from Hokkaido University under the supervision of Prof. Yoichi ${ }_{25}$ Sasaki and Prof. Taira Imamura. Subsequently, he conducted a postdoctoral research with Prof. Koji Tanaka at Institute for Molecular Science. In 2004, he joined to Prof. Yasushi Tsuji's group at Catalysis Research Center, Hokkaido University as a postdoctoral fellow. He was appointed an Assistant Professor at 30 Kyoto University in 2006. His research interests are related to synthesis of nano-scale molecular catalysts as well as development of novel organic transformation catalyzed by transition-metal complexes. 